\title{
Orthopedic Insoles
}

\author{
Gusyev Valentyn* \\ Scientific Research Centre and College of Functional Orthopedics, Canada
}

Submission: August 05, 2019; Published: August 19, 2019

*Corresponding author: Gusyev Valentyn, Professor, engineer biomechanics-prosthetist, D.O.M.P. Osteopathy, Vegatest expert, Scientific Research Centre and College of Functional Orthopedics, 2727 Steeles Ave.West, Unit 306. Toronto, Canada

\section{Opinion}

There are no two identical people and, accordingly, the feet and their deformations. Always one leg is shorter than the other, therefore, as in one scenario, scoliosis, diseases of internal organs develop. And although the first instep insoles were created in 1924 by the Italian Salvatore Ferragamo, there are still no technologies in the world that would restore the functionality of the feet, the spine, and eliminate their deformations. A gross mistake is made by medicine when it does not consider and does not correct the displacement of the Common Center of Gravity of the body, i.e. load on all the articular elements of the skeleton. There is a practice of using rigid orthopedic insoles that are supposedly capable of keeping the arches of the feet in the desired position for the doctor. This is ignored, but rather the pumping function of the feet, the mechanism of the lymph and blood circulation in the body, and the maintenance of the metabolism of all its cells are not understood (Figure 1).

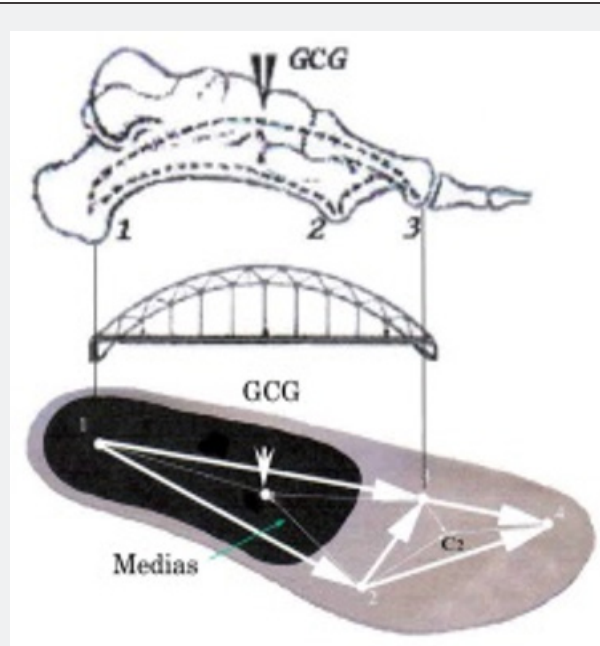

Figure 1: Orthopedic insoles keeping the arches of the feet in the desired position.

Holding the vaults, doctors deprive the foot of the ability to absorb, extinguish the forces of inertia arising during movement, which are 30-50 times greater than the body weight. The foot should rest on the skeletal points. These are the three points of support of the arches. When using rigid insoles, the support is brought under the soft tissues of the vaults, where the muscles pass and cannot contract. This state of the vaults and corresponds to the flatfoot. Without knowing the laws of biomechanics, physics, muscle physiology, and other branches of science, the doctor believes that the heart provides blood circulation in the body. However, he forgets about lymph circulation, one of the components of which is blood. With all the importance of the pumping function of the muscles and the fact that due to the correction of the feet, correction of the spine and other elements of the skeleton is achieved, medicine does not place insoles as medical devices. The reflex nature of all processes in the body is not considered, the reflex effect of insoles on the body, the properties of their materials are not considered. Our research and practice of making insoles indicate how important it is to know what information the insoles carry, what information accumulates in them after a human disease. The quality of the material: its color, the ability to fix - to polarize under the influence of various fields or to block the field of the earth, all this must be known and considered when making insoles, shoes.

Deformities of the feet and spine today are observed in $87 \%$ of the population of developed countries. At the same time, no one beats the bell, as is done in the epidemic of influenza, affecting only $7 \%$ of the population. In fact, with the correction of the elements of the musculoskeletal system, any therapy should begin, since the skeletal muscles are responsible for cell metabolism, nutrition and the elimination of decomposition products. But this does not tell the family doctor, none of the doctors involved. When correcting the feet, first, the forces acting on the skeleton and which are compensated by the muscles should be considered. This means that it is necessary to consider the position of the General Center of Gravity (OST) of the body, which is located at the level of 2-3 vertebra of the lumbosacral region. It is precisely because of the displacement of the body OCT that the disks are displaced and turned around, muscle spasm and pain in this area. There is an overload of one or another department of the foot and the lowering of its arch, which corresponds to the functional shortening of the limb and 
leads to an even greater displacement of the PCT. In this lies the causes of the development of scoliosis, which is aimed at keeping the head in an upright position (Figure 2). Therefore, without correct correction of the feet, compensation of the functional, and then anatomical difference in leg lengths, it is impossible to set the horizontal position of the pelvis, eliminate the scoliotic posture, prevent wear of the joints. All this is something that medicine can not cope with, using rigid insoles, corsets, leading only to greater muscle atrophy. The feeling of cold feet, varicose veins, pain, a disease of the internal organs are all the same disorders in the muscles.

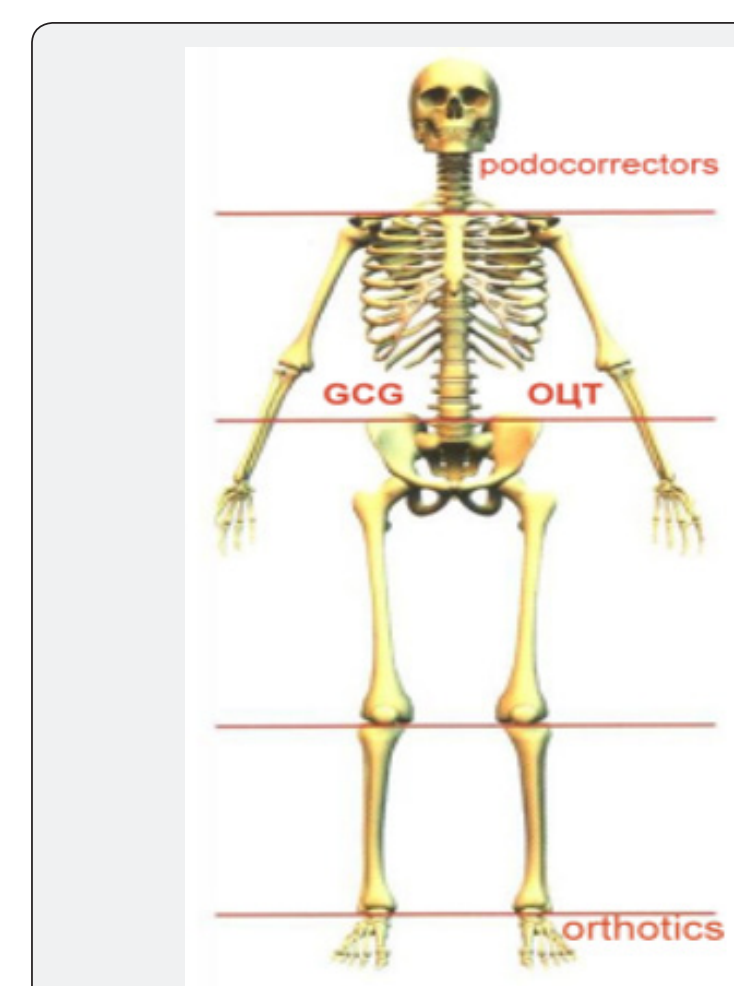

Figure 2: Forces acting on the skeleton.
The techniques of our center are aimed at restoring the functionality of the muscles, their pumping function. This means that through the correction of the feet, the spine, normalization of the work of the whole organism occurs, and without any outside intervention. The organism is a self-regulating system based on cell metabolism processes provided by skeletal muscles.

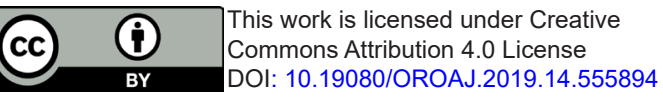

\section{Your next submission with Juniper Publishers will reach you the below assets}

- Quality Editorial service

- Swift Peer Review

- Reprints availability

- E-prints Service

- Manuscript Podcast for convenient understanding

- Global attainment for your research

- Manuscript accessibility in different formats ( Pdf, E-pub, Full Text, Audio)

- Unceasing customer service

Track the below URL for one-step submission https://juniperpublishers.com/online-submission.php 